\title{
THE HISTORICAL DEVELOPMENT AND COMPOSITION OF THE IOWA SUPREME COURT
}

\author{
by Jerry K. Beatty \\ Indianola, lowa
}

Jerry Beatty received his B.A. from Cornell College, Mount Vernon, Iowa in 1963; his M.S. from Northern Illinois, DeKalb in 1965; and his Ph.D. from the University of Iowa, Iowa City in 1970. Dr. Beatty is now serving as an assistant professor of political science at Simpson College, Indianola. The following article is composed of segments from Dr. Beatty's doctoral dissertation.

Warren J. Rees was appointed to the Supreme Court in November of 1969. His term will commence in January of this year; a discussion of his activities and background are, therefore, precluded.

Within one century, the constitutional status of the region presently called Iowa changed over a half dozen times. Discovered and claimed originally by the French in 1673, the territory became part of the Spanish colonial territory in 1762. Spain retroceded the territory to France in 1800, and three years later President Jefferson purchased the land west of the Mississippi from Napoleon. In 1804, the Iowa country was placed under the jurisdiction of the governor and judges of the Territory of Indiana. Eight years later, Iowa was included in the newly created Territory of Missouri. For 13 years after the Missouri Compromise of 1820, the territory north of Missouri and west of the Mississippi was without constitutional status. Between 1834 and 1836, the Iowa country was attached to the Michigan Territory. During this period, there was no specific provision for a judicial organization in Iowa. The judicial department in the Michigan Territorial Government consisted of three judges appointed by the President of the United States for a period of good behavior. There were three judicial districts in the Michigan Territory, one of which included all the present area of Iowa. The Iowa district consisted of two organized counties in each of which 
two sessions of the district court were held annually. In 1836, Congress created the Territory of Wisconsin and included within its confines the area comprising the present state of Iowa. The Wisconsin Territorial Supreme Court consisted of a chief justice and two associate judges appointed by the President of the United States for four-year terms.

On June 12, 1838 Congress established the Territory of Iowa. The Territory included all the area presently called Minnesota and much of the land now comprising the states of North and South Dakota. The territorial judiciary consisted of a chief justice (Charles Mason) and two associate justices (Joseph Williams and Thomas S. Wilson) appointed by the President of the United States with the consent of the Senate for four-year terms. Two judges constituted a quorum for the purpose of transacting business. The Court was required to hold one session a year in the seat of government and each judge was paid an annual salary of $\$ 1,500$. When the Supreme Court was not in session the judges rode circuit and acted as district court judges. The Iowa Territory was divided into three districts with one judge responsible for each area: Mason handled the Lower district, Williams was responsible for the Middle district and Wilson conducted court in the Northern district. As a consequence, the Court would generally review the cases that one of its number had previously tried.

The impact of the Territorial Supreme Court, however, went far beyond the resolution of individual disputes. The first General Assembly passed a resolution asking the judges of the Supreme Court to furnish the legislature with suggested bills which would make possible a code of jurisprudence for Iowa. Subsequently, many of the most important laws adopted at the first session of the Territorial Legislature were written and submitted by the Chief Justice and his associates.

All three judges were Democrats and originally appointed by President Martin Van Buren. When their terms were about to expire, Williams made a trip to Washington to see if he could persuade President John Tyler to reappoint them. Ironically, on his way to Washington, Williams met and became friends with an attractive woman who later was found to be the President's new wife. By the time Williams reached 
the White House, the President had already been persuaded to reappoint the three Iowa Territorial judges. Thus for the eight years of territorial status, Iowa was served by only three high court judges.

During their tenure on the Iowa Territorial Supreme Court, Mason, Williams and Wilson handed down over 216 opinions. Perhaps no decision was more famous than the early decision written by Mason for the Territorial Supreme Court in the case: In the Matter of Ralph on Habeas Corpus. The case involved the rights of a Negro slave working in a free territory. Ralph had entered into a written agreement to work in the Dubuque lead mines to earn $\$ 450$ to pay for his freedom. When Ralph did not meet his payments, his Missouri owner sought to repossess Ralph and take him back to Missouri. Mason's opinion held that although one should honor his contracts this cannot justify the denial or liberty or equal protection under the laws to all people regardless of color and condition. With prophetic foresight, Mason asserted:

... it [the case] involves an important question, which may ere long, if unsettled, become an exciting one. . The master who. . permits his slave to become a resident here cannot afterward exercise any acts of ownership over him within this territory. Property, in slave, cannot exist without the existence of slavery; the prohibition of the latter annihilates the former, and, this being destroyed, he becomes free... When in seeking to accomplish his object, the slave owner illegally restrains a human being of his liberty it is proper that the laws, which should extend equal protection to men of all colors and conditions, should exert their remedial interposition.

Mason's Ralph decision provided a precedent for Justice Benjamin R. Curtis's dissent in the Dred Scott case 18 years later. Again, the issue was whether a Negro slave became free by residing in a free territory. Twenty-two years after Ralph, the unsettled question over slavery became one of the issues which split the Nation and caused the Civil War.

In 1844 steps were taken to secure statehood for the Iowa Territory. A convention held in Iowa City drafted a constitution, but the voters twice rejected the proposed constitution 
largely as a result of dissension over the State boundary. Another issue of debate was whether judges should be popularly elected or chosen by the legislature. The former method prevailed in the unsuccessful 1844 Constitution.

In 1846 another attempt was made at securing statehood and this time the Constitution was ratified by a bare majority. Under the Constitution of 1846, the judicial power of the state was vested in a Supreme Court, four district courts and any other inferior courts which the General Assembly should establish. The Supreme Court consisted of a chief justice and two associates elected by a joint vote of both houses of the General Assembly for six-year terms. The district court judges were elected by the voters in the district for terms of five years. Both the Supreme and the district court judges were ineligible for any other office during the term for which they were elected. The Supreme Court had appellate jurisdiction in all cases of chancery and constituted a court for the correction of error at law. The first General Assembly failed to elect Supreme Court judges and the Territorial judges were continued. Before the July, 1847 term, however, Mason submitted his resignation and the governor appointed Assoc. Justice Williams as chief justice and selected John F. Kenney as the second associate judge. Between 1846 and 1857, 1,800 decisions were rendered by the 11 men who served on the Iowa Supreme Court.

By 1856 the people of Iowa had become dissatisfied with certain restrictive provisions of the 1846 Constitution and a convention was called to' draft a new State constitution. Jacksonian democracy had spread West and the voters now demanded direct popular election of public officials, easy credit, and a less arduous method of amending the Constitution.

The Constitution of 1857 provided for a three-member Supreme Court elected at large by the people of the State for staggered terms of six years-one judge going off every two years. Salary was set at $\$ 2,000$ with subsequent adjustments fixed by law. The legislature was also given the prerogative to prescribe the time and place at which the Supreme Court sessions. would be held. The Supreme Court was given appellate jurisdiction in chancery cases and was authorized to correct errors at law in all cases coming from the District 
Courts, issue writs and processes and exercise a "supervisory control" over all inferior courts in the state. The office of chief justice was to rotate among the members of the court, the judge with the shortest term serving as chief.

Since 1857, the composition and operation of the Iowa Supreme Court has changed in several ways. First, as the work of the Court has increased the number of judges has likewise been increased. The Court was increased to four in 1864, to five in 1867, to six in 1870, to seven in 1915, to eight in 1929 , and since 1931 its membership has been nine. The Supreme Court is also authorized to divide itself into two sections-four justices on each and the chief justice serving as a member of both sections-for the purposes of hearing cases submitted separately to each section of the court. However, since September 1943, the Court has sat en banc.

From 1858 to 1886, the General Assembly provided for oral arguments before the Supreme Court in cities other than the seat of government. Such terms were first held in Davenport, later in Dubuque and finally in Council Bluffs. Parenthetically, the number of Supreme Court sessions or terms in a single year have also altered. In 1860, the law required that the Supreme Court hold two terms annually-in Des Moines-the first Monday in June; the second starting the first Monday in December. The Code of 1870 provided for eight annual terms-two terms each year in Des Moines, Davenport, Dubuque, and Council Bluffs. By 1886 the law was changed to four terms a year in Des Moines. Two years later it was reduced to two terms. Today, the Supreme Court holds three regular sessions a year in Des Moines-the first term beginning the second Tuesday of January and ending the first Monday of May, the second term commencing the first Tuesday after the first Monday of May and terminating the third Monday of September, the final term beginning on the first Tuesday after the third Monday of September and concluding the third Saturday of December. Generally, the Court meets only to hand down decisions in July and does not hold an August session. Since judgments, rulings, and orders in cases can be made at any time, regardless of the term of the Court, the number of terms has no affect on the operation or workload of the Supreme Court. 
In addition, the automatic rotation of the chief justiceship has gone through several phases and has finally been eliminated. The chief justice is now elected by the other members of the Court to serve in this capacity until the expiration of his term, after which he is eligible for re-selection. The chief justice is directed to appoint one of the other members of the Court as his assistant to serve in his place during temporary absence or inability.

The salary of the Supreme Court judges has climbed from $\$ 2,000$ in 1897 to $\$ 22,000$ in 1969 . Nonetheless, as of January, 1969 , only eighteen states gave their highest judges smaller compensation. The salaries of judges of state courts of last resort varied from $\$ 16,000$ to $\$ 39,000$. For expenses, the Iowa Supreme Court judges are reimbursed for travel costs at the rate of ten cents a mile and allowed up to $\$ 15$ a day for board and room while away from home on business.

\section{Judges on the lowa Supreme Court 1838-1969}

Since Iowa became a Territory in 1838, 85 men have served on the Iowa Supreme Court. Traditionally, the typical judge has been a member of the Republican Party, a Protestant church, and the middle or upper-middle class. He has also been married (with children), at least middle-aged; and of British ancestry. His father has generally been a farmer or member of the business or professional class. Before ascending to the Supreme Court most judges have been politically active and have held public office.

Historically, 66 per cent of the judges on the Iowa Supreme Court have been Republicans, 37 per cent have been Democrats and two per cent have been Whigs. The years in which the Democrats have appeared on the Supreme Court coincide with the years Democrats have controlled the Office of Governor. The first seven judges were all Democrats. However, between 1860 and 1932, only one Democrat (La Vega Kinne) was elected or appointed to the Iowa Supreme Court. Kinne's ascendence in 1891 was made possible by the elections of a Democratic Governor (Horace Boise) in 1888 and 1890. From 1932 through 1937, while the Democrats controlled the governorship, 12 Democrats were consecutively selected to the Court. After 1937, however, no Democrat became a member of the Court for two decades. Since 1958, seven Democrats 
and three Republicans have been elevated to the Iowa Supreme Court. The initial selection of both the Democratic and Republican members has been dependent upon the electoral tide at the gubernatorial level. In all, 56 Republicans, 27 Democrats and two Whigs have served on the Iowa Supreme Court.

Most of the judges before coming on the Court have had previous political experience. Ninety-four percent of the Iowa judges have held judicial, legislative or other public offices prior to their selection to the Supreme Court. The greatest shift in the kind of prior political experience has been in the field of legislative experience. Since 1838, the ratio of judges with prior legislative experience has declined from 47 per cent (1838-1900) to 20 per cent (1900-1969). During the same years, the proportion of judges with general public service experience has increased while the percentage with prior judicial experience has subsided slightly-from 60 per cent to 56 per cent.

Analysis of the ages of judges at the time of their initial selection indicates a striking tendency toward selection of older men from 1838 to 1958 . Thomas Ewers found that between 1836-1869 (Period I) most judges were within the 30-40 age bracket, between 1870-1899 (Period II) most of the judges were in their 40's, during the period 1900-1929 (Period III) most judges were between 50 and 60 years old and from 1930 to 1958 (Period IV) the members 60 years and over when elected or appointed equaled the number who were between the ages of 50 and 60 and surpassed the number of those under 50. Since 1958, however, the trend seems to have reversed as seven of the ten new judges selected were under 60. Overall, at the time of their selection to the Supreme Court, one judge was in his 20 's, two judges in their 30 's, 26 judges in their $40^{\prime}$ 's, 29 in their $50^{\prime}$ 's, four in their $60^{\prime}$ 's and five judges in their 70's.

Geographically, there is a growing tendency for judges to live in cities rather than small towns and rural areas at the time of their appointment or election to the Court. The proportion of judges selected in each period who resided in cities of 10,000 population or more is as follows: 19 per cent 
(Period I), 29 per cent (Period II), 44 per cent (Period III) and 65 per cent (Period IV). Since 1958, 70 per cent of the judges elevated to the Court lived in cities of at least 10,000 . The last four judges (Democrats) came from cities over 20,000 population.

The ancestral lineage of most judges can be traced to the British Isles. Forty-one judges have been of British descent, 21 have been American (many generations removed from Europe) six have been of German ancestry and four of Scandanavian descent. The data available indicate that descendents of northwestern Europe have a virtual monopoly in the judicial recruitment process. An historical analysis of judicial composition suggests that the proportion of judges with purely English backgrounds has decreased while the percentage of judges with Irish, Scandanavian and German ancestry has increased. This trend is probably the result of the responsiveness of the political parties to the ethnic change in the Iowa population.

The predominant religious faith of Iowa Supreme Court judges has been Protestant. Eighty-eight per cent of the judges who have served on the Iowa Supreme Court have been affiliated with a Protestant religious denomination. Nineteen judges have been Methodist, 14 Presbyterians, 10 Catholic, eight Episcopalian, six Congregational, and four Baptist. Although nearly 90 per cent of the Protestant judges who have served on the United States Supreme Court were affiliated with religious denominations of "high social status" (e.g., Episcopalian, Presbyterian, Congregational, and Unitarian), the proportion of Iowa Supreme Court judges belonging to high and low status Protestant sects was approximately equal.

One of the most obvious trends concerning the religious background of judges since the turn of the Century has been the decline in the proportion of judges from prestige or upperclass churches and the increased representation of judges from so-called "intermediate" and "low status" religious denominations (e.g., Roman Catholic, Methodist, and Baptist). Whereas five of the eight Episcopalians were selected before 1869, over half of the Methodists and all of the Catholics were elevated to the Supreme Court since 1900. The "low status" 
denomination most under-represented on the Iowa Supreme Court has been the Lutheran faith. Although the Iowa Lutheran membership is second only to the Roman Catholic membership, only one man of this denomination has become a member of the Supreme Court.

As might be expected, most of the judges have come from families of middle to upper-middle class standing. The fathers of 47 judges were farmers; 18 Court members had fathers who were engaged in professional occupations and 12 judges were fathered by businessmen. Only seven judges grew up as members of the working class. Whereas over one-third of the judges were raised in a professional or business environment, less than nine per cent were brought up in lower class surroundings. The trends suggest that the number of judges with a farm heritage is declining, while the proportion of those having fathers in the professions is rising. Fifteen of the 18 judges from professional families and ten of the 12 judges from business backgrounds have ascended to the $\mathrm{Su}-$ preme Court since 1900. Since 1958, 60 per cent of the judges elevated to the Supreme Court had fathers in the professional or business fields, while only 20 per cent had fathers employed as farmers or laborers.

Finally, an overwhelming percentage of the judges have been married men and a large preponderance of them have had children. With one exception, all of the judges elected or appointed to the Iowa Supreme Court have been married and only 12 per cent have been childless. Since 1958, all the judges selected to the Court have been married and between the ten of them they have fathered 44 children.

If present trends continue, one would expect the future judges to: (1) come from business and professional parental backgrounds, (2) be under 60 but over 45 years of age, (3) belong to a "lower-status" religion, (4) have prior public office experience in either the judicial or executive branch, (5) be of native or northwest European lineage, married, and with children. Undoubtedly, new judges will also tend to reflect the party affiliation and/or ideology of the State's chief executive.

In short, the characteristics and experiences of men chosen 
to serve on the Supreme Court have changed over time. In general, the political complexion of the Court was found to reflect the electoral tides at the gubernatorial level. Although some groups and religions have been underrepresented on the Supreme Court, the historical trends concerning the composition of the Court suggest that the social background characteristics of the judges are generally consistent with those of other top level political decision-makers. As expected, the judicial recruitment process in Iowa has a middle to uppermiddle class bias.

\section{Sources and References}

Bicknell, A. D., "The Early Courts of Iowa," Iowa Historical Record, 17 (April 1901), 262-277.

Cole, Cyrenus, A History of the People of Iowa, Cedar Rapids, Iowa: The Torch Press, 1921.

Ewers, Thomas A., "A Study of the Backgrounds of the Successful and Unsuccessful Candidates for the Iowa Supreme Court, 1838-1958," (unpublished M. A. Thesis, University of Iowa, 1959).

Grossman, Joel B., "Social Backgrounds and Judicial DecisionMaking," Harvard Law Review, 79 (June 1966), 1551-1564.

Higgins, Timothy, "Justices of the Wisconsin Supreme Court," Wisconsin Law Review, 1949 (July 1949), 738-760.

Palimpsest, Iowa State Historical Society, Iowa City: 'Johnson, Jack T., "A Judge Well Met (Joseph Williams)," (September 1938); Mahan, Bruce E., "Judge Joseph Williams," (March 1924); Robeson, George G., "Justice in Early Iowa," (March 1924); "The Case of Ralph" (February 1926); "The Supreme Court in Session," (June 1939).

Parrish, John C., "An Early Fugitive Slave Case West of the Mississippi River," Iowa Journal of History and Politics, 6 (January 1908), 88-95.

Peterson, Henry K., "The First Decision Rendered by the Supreme Court of Iowa," Annals of Iowa, 34 (April 1958), 304307.

Schmidhauser, John R., "The Justices of the Supreme Court: A Collective Portrait," Midwest Journal of Political Science, 3 (February 1958), 1-57.

Swisher, Jacob R., "The Judiciary of the Territory of Iowa," Iowa Journal of History and Politics, 20 (April 1922), 224-275.

Toussaint, Willard I., "Charles Mason's Influence on Iowa Jurisprudence," Annals of Iowa, 39 (Summer, 1968), 372-387.

Wennerstrum, Charles F., "Historical Development of the Judicial System in Iowa," Annals of Iowa, 35 (Winter, 1961), 491522. 
Copyright of Annals of Iowa is the property of State of Iowa, by \& through the State Historical Society of Iowa and its content may not be copied or emailed to multiple sites or posted to a listserv without the copyright holder's express written permission. However, users may print, download, or email articles for individual use. 